\title{
Solid-phase synthesis of peptide-dendrimer conjugates for an investigation of integrin binding
}

\author{
Seán Monaghan, ${ }^{a}$ David Griffith-Johnson, ${ }^{b}$ Ian Matthews ${ }^{c}$, and Mark Bradley. ${ }^{a *}$ \\ a Department of Chemistry, University of Southampton, \\ Highfield, Southampton SO17 1BJ, \\ b Antisoma Research Laboratories, St Georges Hospital Medical School, \\ Tooting, London SW17 0QS, c Chemovation LTD, The Yammond, \\ North heath lane RH12 5QE, UK.
}

(received 05 Sep 01; accepted 22 Oct 01; published on the web 30 Oct 01)

\begin{abstract}
Peptide-dendrimer conjugates, bearing up to eight peptide ligands (LDV) targeted against the $\alpha 4 \beta$ integrin VLA-4 were prepared by solid-phase synthesis. Solid phase synthesis allowing the dendrimer conjugates to be prepared in high purity for an investigation of the multivalent effect in ligand integrin interactions. An ELISA was used to screen the peptide-dendrimer conjugates for their ability to compete with a biotinylated peptide component of the CS1 region of fibronectin. The inhibition potential of the different generation peptide-dendrimer conjugates was found to increase with higher generations.
\end{abstract}

\section{Introduction}

Cell-cell and cell-matrix interactions are involved in a number of disease states, most notably cancer metastasis and various inflammatory conditions for example rheumatoid arthritis and asthma. ${ }^{1-5}$ They are also involved in many physiological processes including the immune response, wound healing, embryogenesis and cell differentiation. Integrins appear to be the major receptors by which cells attach to the extracellular matrix. The integrin VLA-4 or $\alpha_{4} \beta_{1}$ (the integrin studied here) is found on numerous cell types including tumor cells, lymphocytes and eosinophils. The ability to affect integrin function therefore offers many opportunities for therapeutic intervention.

Fibronectin $^{6.8}$ is a cell adhesion protein widely distributed in the tissues of all vertebrates and is present as a polymeric fibrillar network in the extracellular matrix and as soluble protomers in body fluids. Significantly, it contains at least two major domains that support cell adhesion. The counter ligand for VLA-4 includes both VCAM-1 (found on vascular endothelial cells) and a peptide motif found within fibronectin. The minimal essential peptide sequence in both ligands is LDV. This is analogous to the RGD motif (also present in fibronectin), which is a ligand for a wide variety of integrin receptors in particular $\alpha_{\operatorname{lib}} \beta_{3}$ and $\alpha_{\mathrm{v}} \beta_{3}$. The affinity of these tripeptides is 
however low when compared to fibronectin in cell adhesion assays ${ }^{9}$ which has an IC50 value of 9 $\mathrm{nM}$. This is because high avidity interactions result due to multivalent interactions. Recently various polymers have been used to improve carbohydrate protein interactions using the multivalent effect. ${ }^{10-17}$ Dendrimers are mono-disperse multivalent polymers and provide excellent templates for the multivalent expression of biologically active ligands. Dendrimer conjugates were investigated here as a possible way to increase the affinity of the weak binding ligand, (LDV), to the $\alpha_{4} \beta$ integrin using solid-phase synthesis to allow efficient dendrimer conjugation.

\section{Results and Discussion}

\section{(a) Synthesis of multivalent dendritic scaffolds}

Taking advantage of the solid-phase PAMAM dendrimer chemistry already developed in our laboratories, ${ }^{18}$ dendrimer synthesis (Scheme 1) started from the initiator core 1, which was treated with 250 equivalents of methyl acrylate in methanol for $2 \times 48 \mathrm{hrs}$ at $50^{\circ} \mathrm{C}$ followed by removal of excess reagents by filtration and thorough washing (DCM, DMF, $\mathrm{MeOH}, \mathrm{Et} 2 \mathrm{O}$ ). To monitor the formation of half-generation dendrimers electrospray mass spectrometry was used as it could detect the presence of any defects. This was important, as defect structures arising from retroMichael additions and intramolecular cyclic amide formation can cause problems. ${ }^{19}$ The half generation dendrimer was then treated with 1, 3 diaminopropane in DMSO for $72 \mathrm{hrs}$ at $50^{\circ} \mathrm{C}$ and then again at room temperature for a further $72 \mathrm{hrs}$ to form the next full generation dendrimer.

Solid-phase dendrimer synthesis was also performed using the trifunctional dendrimer building block, dimethyl 6-isocyanato-6-(4-carbomethoxy-2-oxabutyl)-4, 8dioxaundecanedioate, pioneered by Newkome et al. ${ }^{19}$ Displacement of the methyl ester was performed by treatment with 1,3-diaminopropane in DMSO affording a dendrimer 4 with six ligand sites. Dendritic purity in all cases was evaluated by attaching a chromophore to a small amount of resin linked dendrimer which was then cleaved with $90 \%$ TFA in DCM and analysed by HPLC.

\section{(b) Synthesis of Peptide-Dendrimer Conjugates}

The solid-phase immobilized dendrimeric scaffold allowed the coupling of a range of biologically active ligands. The peptides (LDV and EILDVPST) was synthesised on the dendrimer resins using standard Fmoc solid-phase peptide chemistry. Couplings were performed with 5 equivalents of HOBt, DIC and amino acid, in DMF. Following dendrimer-peptide conjugate synthesis, deprotection and cleavage with 90\% TFA in DCM, the cleaved products were dissolved in acetic acid, concentrated and precipitated with ether, centrifuged and freeze dried. The dendrimer conjugates were subsequently purified by semi-preparative RP-HPLC and were of exceptional purity, without any defect structures, something which is usually difficult to 
obtain with large molecules of this type. The peptide sequence EILDVPST, (from the CS-1 region of fibronectin), was coupled onto 4 using standard peptide coupling conditions to give the dendrimer conjugate $5 \mathbf{a}$ in good yield and purity ( $>90 \%$ by HPLC, $\lambda=220 \mathrm{~nm})$.

\section{(c) LDV Peptide Screening Assay}

The dendrimer conjugates were evaluated for their ability to inhibit the binding of biotinylatedEILDVPST-NH 2 to the $\alpha_{4} \beta_{1}$ integrin adhesion receptor expressed on cancer cells grown on 96 well-plates. Thus peptide EILDVPST-NH2 6 was compared to the hexavalent form 5a (prepared from dendrimer 4) in a competition ELISA. Binding results showed (Figure 1) that the dendrimeric presentation of the EILDVPST sequence increased its affinity 12-fold, significantly more than the statistical increase in ligand number, showing the advantage of multiple valancy. The minimum active peptide sequence in fibronectin is LDV. Dendrimeric compounds bearing only LDV were also synthesized (Figure 2). However they showed little or no activity in competition with the fuller length biotinylated peptide EILDVPST-NH2. A small library of multiple-valent compounds based on LDV but in which the capping group at the N-terminus was varied based on previous reports ${ }^{20}$ of efficient capping groups was synthesized. Ligand a was found to be the best ligand and $\mathbf{b}$ the most water soluble. This led to the series of compounds shown in Figure 3, which also allowed an investigation into the effect of spacer length on potency by incorporating 1, 2, or 3 residues of Fmoc-6-aminohexanoic acid followed by ligands $\mathbf{a}$ or $\mathbf{b}$ to afford compounds 6-12. Screening (Figure 4) showed that there were no real benefit of increasing the spacer length, but the capping group has a huge effect on binding.

The solid-phase strategy presented here is an ideal method allowing the generation of extremely clean monodisperse peptide-dendrimers for the investigation of the multivalent effect in ligand integrin interactions. The materials generated were essentially homogeneous, a non-trivial task for compounds of this size and type (for example dendrimer 4 conjugated with the peptide EILDVPST (conjugate 5a) has a mass of (6329 Da)). The multiple valency approach was successful, but only to a limited degree. Clearly this indicates that spatial organization of the peptide array needs to be optimized to ensure high affinity binding. 


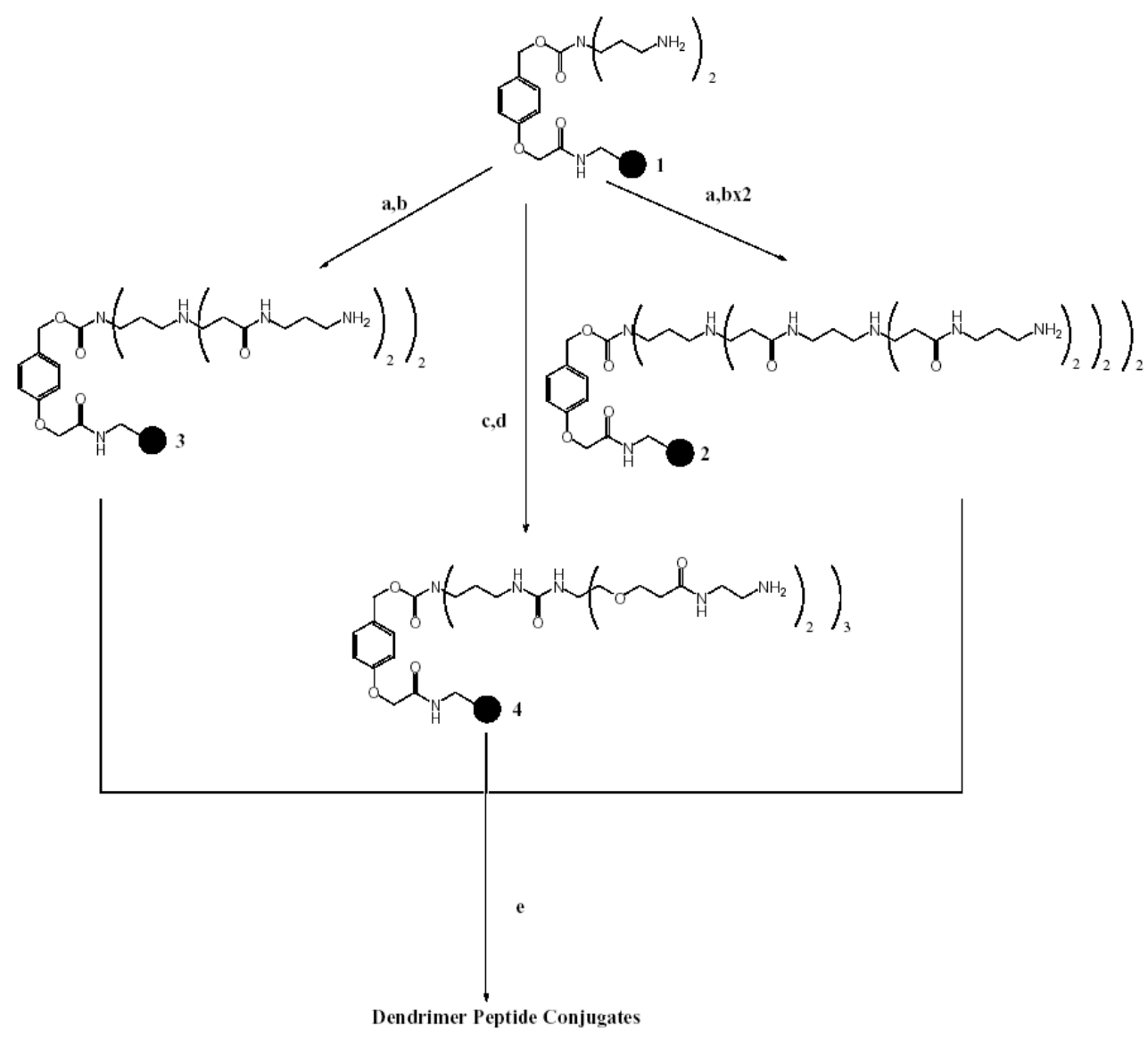

Scheme 1. (a) Methyl acrylate, $\mathrm{MeOH}$; (b) 1,3-propanediamine, $\mathrm{MeOH}$; (c) $\mathrm{OCNC}\left(\mathrm{CH}_{2} \mathrm{OCH}_{2} \mathrm{CO}_{2} \mathrm{Me}\right)_{3}$, DMAP, DIPEA, DCM; (d) Ethylene diamine, DMSO; (e) FmocPeptide synthesis; (f) 90\% TFA/DCM.

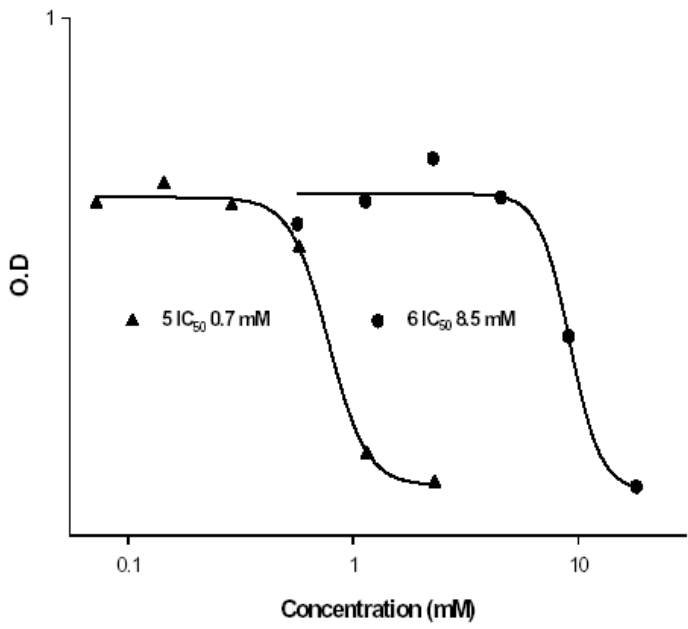

Figure 1. ELISA of $(5 a)=$ Dendrimer (4)-conjugated to (EILDVPST) 6 and monomeric peptide (6) = EILDVPST-NH 2 competing against biotinylated EILDVPST-NH $2(1 \mathrm{mM})$. 

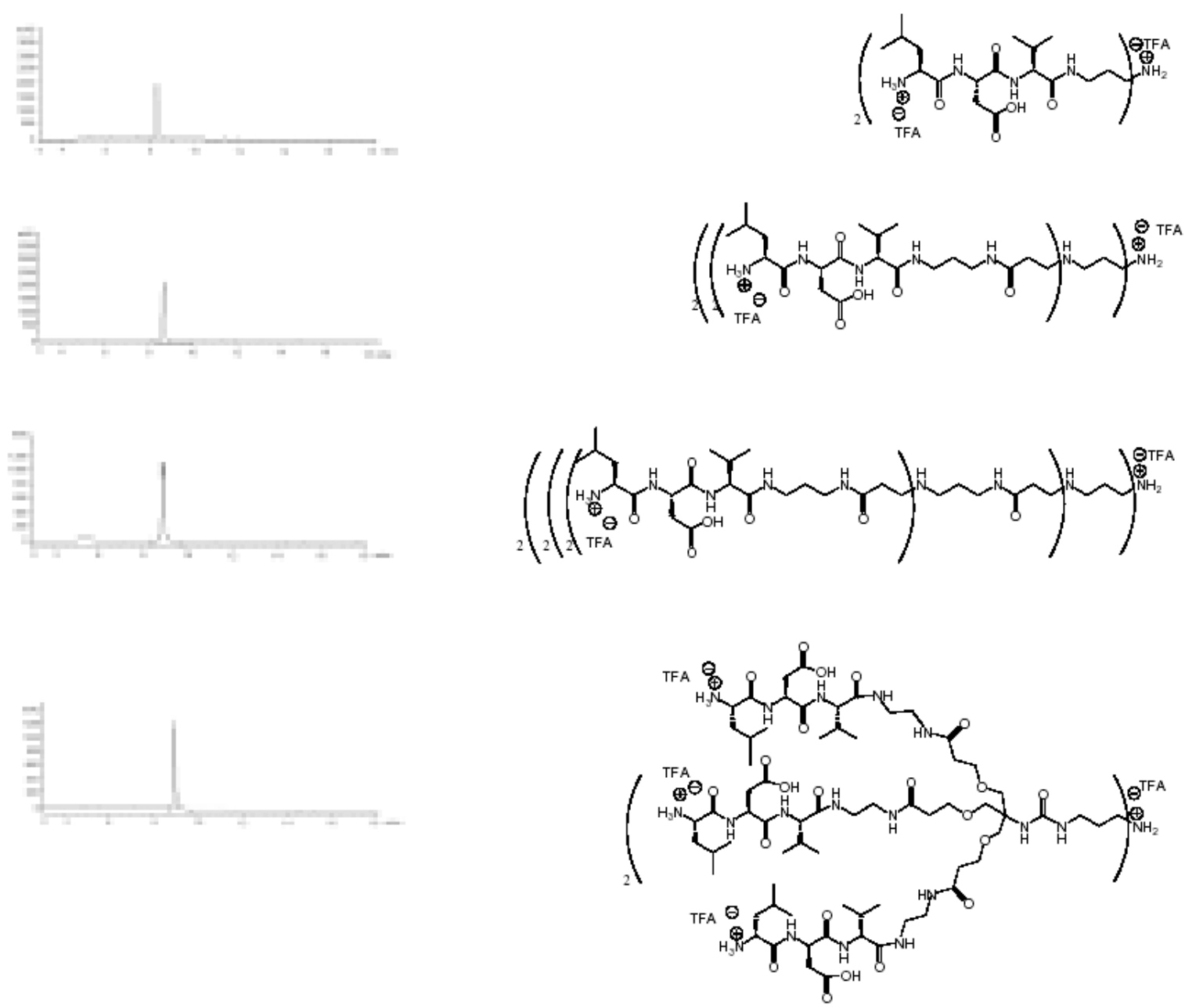

Figure 2. Structure and HPLC traces of LDV-dendrimer conjugates synthesized. 
<smiles>CC(C)C[C@H](NC(=O)c1ccc(Oc2ccccc2)cc1)C(=O)N[C@@H](CC(=O)O)C(=O)N[C@H](C(C)C)C(C)(C)C</smiles>

a<smiles>CC(C)C[C@H](NC(=O)Cc1ccc(O)cc1)C(=O)N[C@@H](CC(=O)O)C(=O)N[C@H](C(=O)[Y](C)(C)C)C(C)C</smiles>

b<smiles>[Y]NCCCNC(=O)CCOCC(C)(CC)NC(=O)NCCC(C)NCC</smiles>

6: $X=a, m=0$

7: $X=a, m=1$

8: $X=b, m=1$

9: $X=a, m=2$

10: $X=b, m=2$

11: $X=a, m=3$

12: $\mathrm{X}=\mathrm{b}, \mathrm{m}=3$

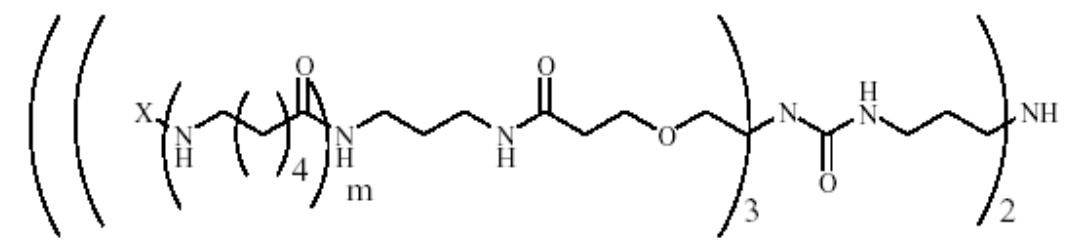

Figure 3. Dendrimer Array Compounds.

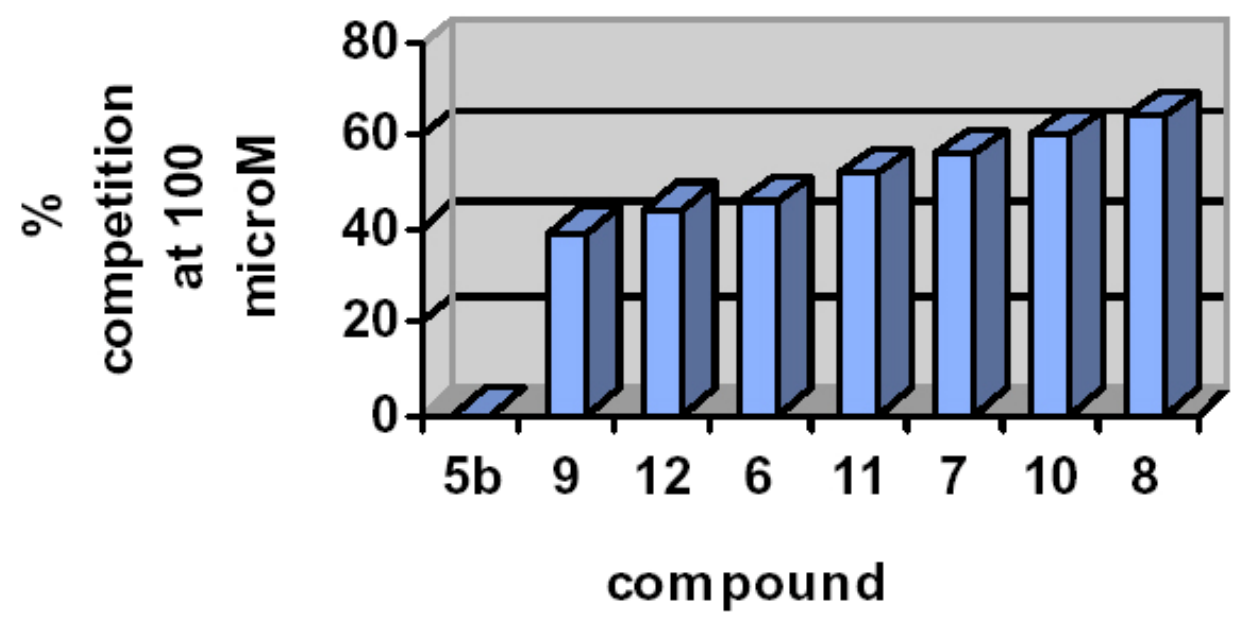

Figure 4. Percentage inhibition of biotinylated EILDVPST- $\mathrm{NH}_{2}(100 \mu \mathrm{M})$ binding by multivalent compounds at $(100 \mu \mathrm{M})$ concentration. 


\section{Experimental Section}

Analytical HPLC was performed on a HP1100 system equipped with a Phenomenex Prodigy $\mathrm{C}_{18}$ reverse phase column $(150 \times 4.66 \mathrm{~mm})$ with a flow rate of $1 \mathrm{~mL} / \mathrm{min}$. Monitoring at the wavelength $220 \mathrm{~nm}$ eluting with $10-90 \% \mathrm{MeCN} /(0.1 \%$ TFA $)$ over 20 minutes. A375M melanoma cells (CRL-1619, American Tissue Culture Collection, Manassas, US). Cells were plated at $2.5 \times 10^{4}$ cells $/ 100 \mu \mathrm{L}$ medium/well into 96 well plates. Twenty-four hours later media was gently removed and $100 \mu \mathrm{L}$ of $0.25 \%$ glutaraldehyde was added to each well for 30 minutes. This was subsequently removed and $100 \mu \mathrm{L} \mathrm{PBS} / 0.05 \% \mathrm{w} / \mathrm{v}$ azide added to each well for storage at $4{ }^{\circ} \mathrm{C}$. After washing three times in PBS containing $0.05 \% \mathrm{v} / \mathrm{v}$ Tween 20 (the wash buffer) the plate was blocked with $10 \% \mathrm{w} / \mathrm{v}$ BSA in PBS for 1 hour at $37^{\circ} \mathrm{C}, 200 \mu \mathrm{L} /$ well. After a washing step, biotinylated EILDVPST (100 $\mu \mathrm{L} /$ well in duplicates) was added in the presence and absence of the competing peptide/dendrimer conjugate. The plate was incubated at $37^{\circ} \mathrm{C}$ for 1 hour. After thoroughly removing the unbound biotinylated peptide Neutravidin Horseradish peroxidase $(2.0 \mu \mathrm{g} / \mathrm{mL}, 100 \mu \mathrm{L} /$ well, Pierce Chester, UK) was added to each well and incubated for 1 hour at $37^{\circ} \mathrm{C}$. After washing off unbound enzyme $100 \mu \mathrm{L}$ of the substrate o-phenylenediamine (OPD) dihydrochloride (Sigma, Poole, Dorset, UK) was added to all wells and the plate incubated for 40 minutes at room temperature in the dark before measuring the absorbance at $450 \mathrm{~nm}$.

\section{Acknowledgements}

We thank the BBSRC and Antisoma for funding

\section{References}

1. Mousa, S. A.; Cheresh, D. A. Drug Discovery Today 1997, 2, 187.

2. Hynes, R. O. Cell 1987, 48, 549.

3. Hynes, R.O. Cell 1992, 69, 11.

4. Haubner, R.; Finsinger, D.; Kessler, H. Angew. Int. Ed. Engl. 1997, 36, 1374.

5. Poste, G.; Fidler, I. J. Nature 1980, 139.

6. Johansson, S.; Svineng, G.; Wennerberg, K.; Armulik, A.; Lohikangas, L. Frontiers in Bioscience 1997, 2, 126.

7. Komoriya, A.; Green, L., J; Mervic, M.; Yamada, S. S.; Yamada, K. M.; Humphries, M. J. J. Biol. Chem. 1991, 266, 15075.

8. Ruoslahti, E. Annu. Rev. Cell Dev. Biol. 1996, 12, 697.

9. Hautanen, A.; Gailit, J.; Mann, D. M.; Ruoslahti, E. J. Biol. Chem. 1989, 264, 1437.

10. Zanini, D.; Roy, R. J. Org. Chem. 1996, 61, 7348.

11. Zanini, D.; Roy, R. J. Am. Chem. Soc. 1996, 119, 2088. 
12. Wittmann, V.; Takayama, S.; Gong, K. W.; Weitz-Schmidt, G.; Wong, C. H. J. Org. Chem. 1998, 63, 5137.

13. Roy, R.; Saha, U. K. Chem. Commun. 1996, 201.

14. Mortell, K. H.; Weatherman, R. V.; Kiessling, L. L. J. Am. Chem. Soc. 1996, 118, 2297.

15. Strong, L. E.; Kiessling. L. L. J. Am. Chem. Soc. 1999, 121, 6193.

16. Choi, S. K.; Mammen, M.; Whitesides, G. M. J. Am. Chem. Soc. 1997, 119, 4103.

17. Sigal, G. B.; Mammen, M.; Dahmann, G.; Whitesides, G. M. Angew. Chem. Int. Ed. 1998, 2754.

18. (a) Marsh, I. R.; Smith, H. K.; Leblanc, C.; Bradley, M. Molecular Diversity 1996, 2, 165.

(b) Swali, V.; Wells, N. J.; Langley, G. J.; Bradley, M. J. Org. Chem. 1997, 62, 4902. (c)

Wells, N. J.; Basso, A.; Bradley, M. Biopolymers 1998, 47, 381396.

19. (a) Newkome, G. R., Weis, C. D., Childs, B. J. Designed Monomers and Polymers 1998, 1, 3. (b) Bosman, A. W.; Janssen, H. M.; Meijer, E. W. Chem Rev. 1999, 99, 1665.

20. Lin, K.; Ateeq, H.; Hsiung, S. H.; Chong, L. T.; Zimmerman, C. N.; Castro, A.; Lee, W.; Hammond, C.; Kalkunte, S.; Chen, L.; Pepinsky, R. B.; Leone, D. R.; Sprague, A. G.; Abraham, W. M.; Gill, A.; Lobb, R. R.; Adams, S. P. J. Med. Chem. 1999, 42, 920. 